\title{
A new species of Benthana (Crustacea: Isopoda: Philosciidae) from southern Brazil
}

\author{
Carolina C. Sokolowicz; Paula B. Araujo \& Juliana F. Boelter
}

Departamento de Zoologia, Universidade Federal do Rio Grande do Sul. Avenida Bento Gonçalves 9500, prédio 43435, 91501-970 Porto Alegre, Rio Grande do Sul, Brasil.E-mail: carolinasokolowicz@hotmail.com; pbaraujo@portoweb.com.br; julianaboelter@gmail.com

\begin{abstract}
A new species of Benthana Budde-Lund, 1908 is described from southern Brazil. Benthana cairensis sp. nov. is distinguished from the other species in the genus by having 17 aesthetascs on the antennula and the elongated male pleopod 1 exopod with a lobe on the inner lateral margin and up to six setae on the outer lateral margin. The new species most resembles B. olfersii (Brandt, 1833), but may be distinguished by lacking the lobe with six setae on the internal margin of the proximal extremity of the merus of pereiopod 7. Furthermore, we include B. olfersii in the subgenus Benthanoscia based on the examined material as described herein.
\end{abstract}

KEY WORDS. Neotropical; Oniscidea; terrestrial isopod.

RESUMO. Uma nova espécie de Benthana Budde-Lund (Crustacea: Isopoda: Philosciidae) sul do Brasil. Uma nova espécie de Benthana Budde-Lund, 1908, é descrita de material coletado no sul do Brasil. B. cairensis sp. nov. distingue-se das outras espécies do gênero por apresentar 17 estetascos na antênula e o exópode do pleópode 1 do macho alongado, com um lobo e portando seis setas na margem lateral externa. A nova espécie assemelhase a $B$. olfersii (Brandt, 1833) em várias características, mas pode ser diferenciada pela ausência do lobo com seis setas na margem externa da extremidade proximal do mero do pereiópodo 7. Além disso, B. olfersii é incluída, neste trabalho, no subgênero Benthanoscia, com base no material examinado.

PALAVRAS-CHAVE. Isópodo terrestre; neotropical; Oniscidea.

Nineteen species of Benthana Budde-Lund, 1908 (LeIsTiKow \& Wägele 1999, Araujo \& Lopes 2003) are found in eastern tropical and subtropical South America (Leistikow 2001). Five species have been reported in the state of Rio Grande do Sul (RS): $B$. picta Araujo \& Buckup, 1994, B. taeniata Araujo \& Buckup, 1994, B. serrana Araujo \& Lopes, 2003, B. trinodulada Araujo \& Lopes, 2003, and B. araucariana Araujo \& Lopes, 2003. The genus is characterized by two autapomorphies: the cordiform shape of the male pleopod 1 exopod with a lateral dentiform protusion, and the robust distally dentate seta on the carpus of pereiopod 1, slightly merged with the cuticular stalk (Leistikow 2001, LeistiKow \& ARAujo 2006).

Leistikow (2001) proposed a phylogeny of the South American Philosciidae that he considered paraphyletic. Benthana is included as a sister group of Atlantoscia and Rhyscotidae, and these three taxa together form the new Benthana-group with the autapomorphy being the maxillipedal endite without setae, distal margin transverse.

Lemos de CASTRO (1958a) described Benthanoscia longicauda$t a$, a new species and genus of philosciid from eastern Brazil that he did not include in Benthana. Leistikow \& Araujo (2006), however, proposed that Benthanoscia should be interpreted as a subgenus of Benthana with sexually dimorphic uropods as an autapomorphy.
Here, we describe a new species of Benthana based on material collected in the municipality of Taquara and Sapiranga, in eastern Rio Grande do Sul, southern Brazil.

\section{MATERIAL AND METHODS}

Pleopod 1 exopod shape in males (z:y ratio) was defined following the morphometric method of ARAUjo \& Lopes (2003). Measurements of noduli laterales were obtained as in VANDEL (1962). Drawings were prepared using a camera lucida; pereiopods were prepared for analyses with Scanning Electron Microscopy (SEM) following LeIsTiKow \& Araujo (2001). The material examined of Benthana olfersii (Brandt, 1833) is MNRJ 8145 and MNRJ 8152.

The holotype and paratypes were deposited in the Museu Nacional (MNRJ), Universidade Federal do Rio de Janeiro, Rio de Janeiro; Museu de Zoologia (MZUSP), Universidade de São Paulo, São Paulo; and in the Crustacean Collection of the Department of Zoology, Universidade Federal do Rio Grande do Sul (UFRGS), Porto Alegre.

\section{Benthana Budde-Lund, 1908}

Type species: Benthana picta (Brandt, 1833)

A diagnosis of the genus and a key to distinguish Benthana

Revista Brasileira de Zoologia 25 (2): 314-318, June, 2008 
from the other Neotropical genera of Philosciidae are found in Araujo \& Leistikow (1999) and Leistikow (2001), respectively.

\section{Benthana cairensis sp. nov.}

Figs 1-28

Material. Holotype: male, BraziL, Rio Grande do Sul: Taquara $\left(29^{\circ} 46^{\prime} \mathrm{S}, 50^{\circ} 50^{\prime} \mathrm{W}\right.$, Sítio Cairé, in leaf litter), 25.IV.2004 (MNRJ 20574). Paratypes: same locality as holotype, 1 male and 1 female, 26.II.2007 (MZUSP 17362) and 5 males and 5 females, 26.II.2007 (UFRGS 4399), 5 males and 5 females, 19.III.2007 (UFRGS 4421) and 5 males and 5 females, 23.III.2007 (UFRGS 4422); Sapiranga $\left(29^{\circ} 37^{\prime} 52^{\prime \prime} \mathrm{S}, 51^{\circ} 00^{\prime} 34^{\prime \prime} \mathrm{W}\right), 8$ males, 7 females, 29.XII.2001 (UFRGS 4471).

Diagnosis. Eye with 22-25 ommatidia, antennula with $15+2$ aesthetascs; antenna, when extended posteriorly, reaches anterior margin of the fifth pereionite; lateral endite of maxillula with $4+6$ setae, five of inner set pectinate, proximal teeth with $5+1$ denticles. Male exopod of pleopod 1 elongated (sensu Araujo \& Lopes 2003), with lobe on inner lateral margin; bearing up to 6 setae on outer lateral margin. Exopods and endopods of uropods inserting at different levels.

Description. Maximum cephalothorax width: male 1.70 $\mathrm{mm}$, female $2.60 \mathrm{~mm}$. Maximum length: male $9.7 \mathrm{~mm}$, female $11.5 \mathrm{~mm}$. Body color chestnut, with unpigmented regions along pereion; unpigmented spots on anterior region of each coxal plate; elongated unpigmented lines on median longitudinal part of the pereionites (Fig. 1). Antenna articles 1-5 with few small areas without pigmentation; flagellum uniformly chestnut colored. Pleonites 1-2 with three unpigmented spots, pleonites 3-5 with elongated spots with fine lateral projections without pigmentation on median longitudinal line. Pleotelson with same pattern of pleonites 3-5. Uropods uniformly pigmented. Pereiopods partially pigmented. Pereion with smooth and bright tegument bearing setae on all pereionites. Noduli laterales (Figs 15 and 16) with $\mathrm{d} / \mathrm{c}$ coordinates showing a maximum on pereionite 4 . Pleon narrows abruptly in relation to pereion; neopleura well-developed on segments $3-5$. Pleotelson triangular with slightly concave lateral margins, and with rounded apex, reaching more than halfway down the protopodite of uropods. Cephalothorax with eyes having 22-25 ommatidia. Antennula with coniform distal article with five rounds of three aesthetascs each and two apical aesthetascs (Fig. 2). Antenna, when extended posteriorly, reaches anterior margin of fifth pereionite. Antenna article 5 and flagellum approximately same length. Second flagellar article smallest, apical organ about onethird the size of distal article (Fig. 3). Mandibles: right mandible with two penicils on incisor process and tuft of at least 10 plumose setae on molar (Fig. 4); left mandible with three penicils on incisor process and tuft of at least 10 plumose setae on molar (Fig. 5). Maxillula: lateral endite with $4+6$ setae, five of inner set pectinate, proximal teeth with $5+1$ denticles (Fig. 6), medial endite with two apical penicils; (Fig. 7). Maxilla: external lobe with sinuous posterior margin and internal mar- gin with three long and fine setae (Fig. 8). Maxilliped: endite with long and short seta; two short teeth on the distal external margin, with three small protuberances. Apex of palp with tuft of short fine setae (Fig. 9). Pereiopods: with tricorns on all articles, antenna-groming brush of the carpus and dentate carpal seta present on pereiopod 1 (Fig. 27). Uropod: insertion of endopod and exopod at different levels, endopod extending to half of exopod (Fig. 1). Sexual differentiation: pereiopods 1-4 of male with rows of bifid setae, particularly on merus and carpus, missing in female; ischium and merus of all pereiopods of male of sub-equal length. In males, ischium of pereiopod 7 robust with setae approximately in the middle; in females, ischium with setae on distal third (Figs 17-26). Pleopods: in males, elongated exopod of pleopod 1 (z:y ratio $=3.1$, excluding the lobe), with subapical dentiform expansion and lobe on inner lateral margin and up to six setae on outer lateral margin (Fig. 10), endopod with five fine pical spines (Fig. 11). Pleopod 2 with exopod distally elongated carrying setae on external margin, endopod tapered on distal third (Figs 12 and 13). Pleopod 5 exopod with up to approximately nine setae on external lateral margin (Fig. 14).

Etymology. The specific name refers to a location, Sítio Cairé, at which the species was found, in Taquara, Rio Grande do Sul, Brazil.

Remarks. Benthana cairensis sp. nov. has $5+1$ denticles in the proximal teeth of the lateral endite in the maxillula, while the other 19 species have at least $6+1$ denticles. The new species does have characteristics found in other congeneric species, such as: the lobe on the inner lateral margin on the male exopod of pleopod 1 and setae on the opposite margin, five pectinate teeth on the lateral endite of the maxillula, insertion of the endopod and exopod at different levels, and male sexual dimorphism on pereiopods 1-3(4).

Three species of the genus have a lobe on male pleopod 1 exopod: 1) B. serrana, lacks setae on the pleopod 1 exopod and has 20 ommatidia (22-25 on the sp. nov.); 2) B. taeniata, also lacks setae on pleopod 1 exopod, has endopod and exopod insertions of the uropod at the same level, sexual dimorphism of males only in the first pereiopod and 17 to 19 ommatidia; and 3) B. olfersii has all of the characteristics for B. cairensis sp. nov. except that the sexual dimorphism of males is restricted to the pereiopods $1-3$, and, uniquely, a lobe with six setae on the internal margin of the proximal extremity of the merus on pereiopod 7 (Fig. 28).

In a review of Benthana, sexual dimorphism was described on the exopodites of the uropods, which are longer in males than in females (Lemos DE CASTRO 1958b). In B. olfersii studied here, one male and one female of similar size were examined and had this same dimorphism and so this species should be included in the subgenus Benthanoscia, in which dimorphism on male exopodites is an autapomorphy (LeISTIKow \& AraUjo 2006). Therefore, by lacking this dimorphism (autapomorphy), the new species is not included in the subgenus Benthanoscia. 


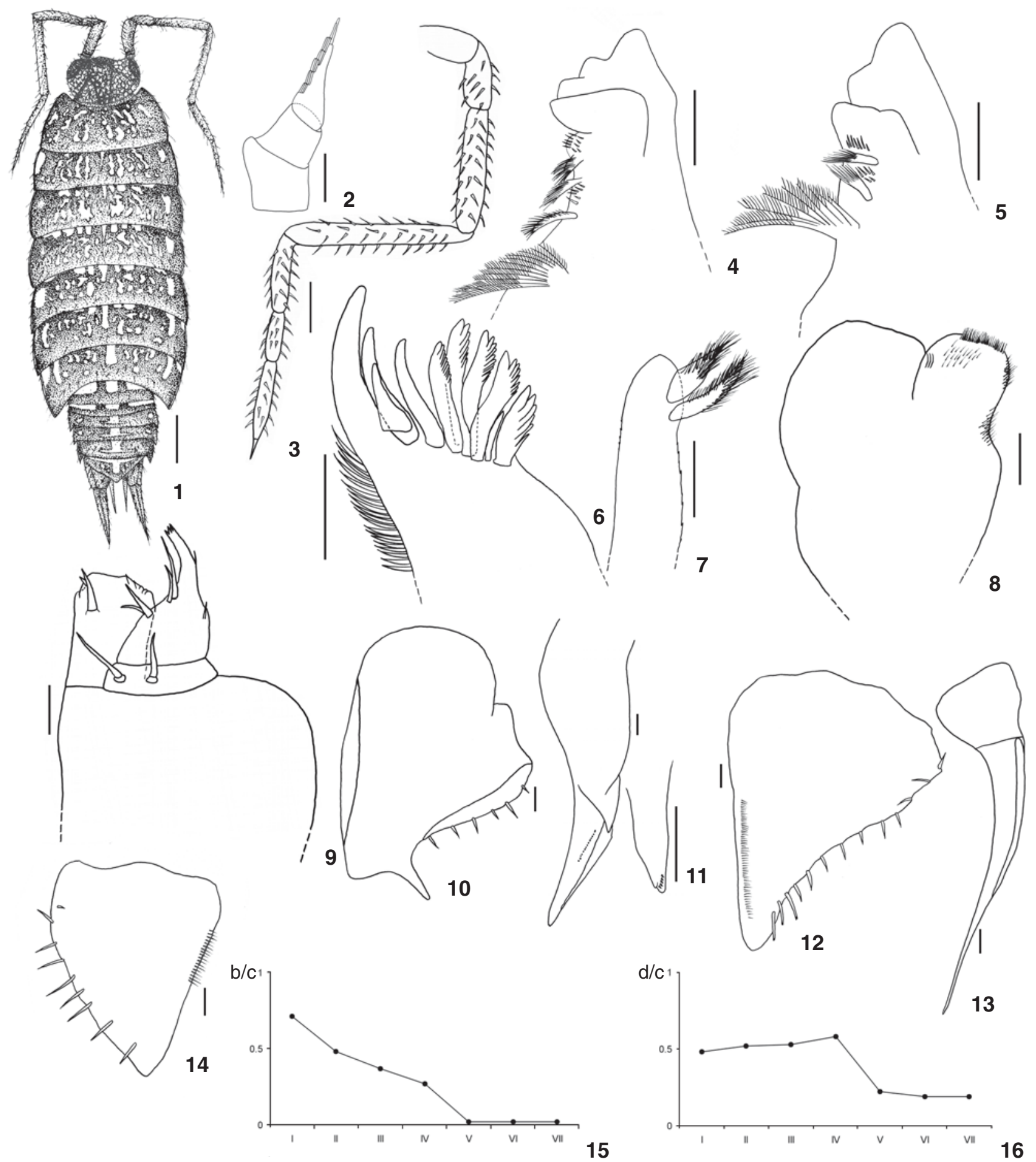

Figures 1-16. Benthana cairensis sp. nov. Male: (1) dorsal view; (2) antennula; (3) antenna; (4) right mandible; (5) left mandible; (6) lateral endite of maxillula; medial endite of maxillula; (8) maxilla; (9) maxilliped; (10) pleopod 1 exopod, (11) pleopod 1 endopod, with detail of five small spines; (12) pleopod 2 exopod; (13) pleopod 2 endopod; (14) pleopod 5 exopod; (15-16) co-ordinates b/c and d/c of the noduli laterales. Scales: $1.0 \mathrm{~mm}$.

Revista Brasileira de Zoologia 25 (2): 314-318, June, 2008 


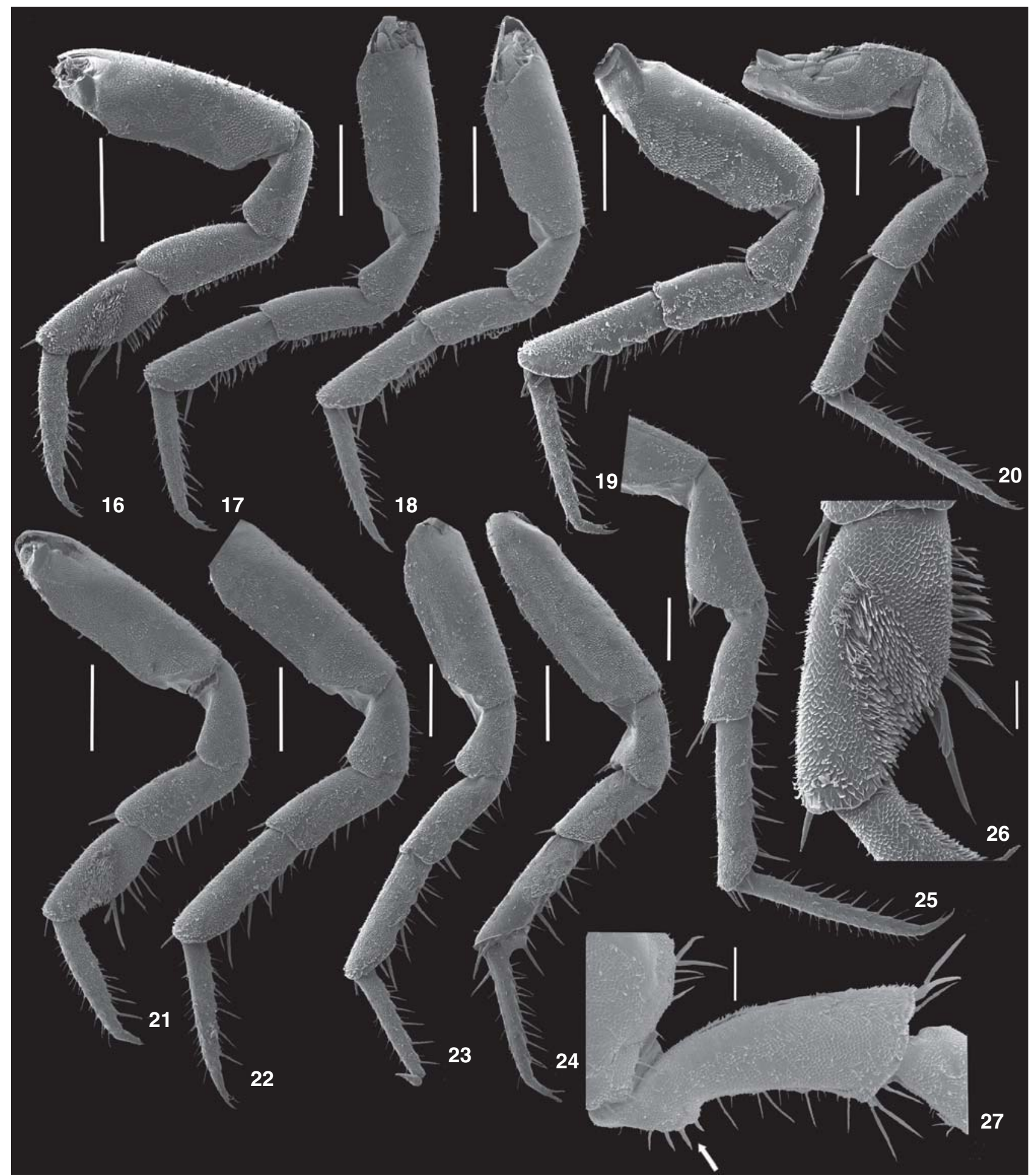

Figures 17-28. Benthana cairensis sp. nov.: (17) male pereiopod 1; (18) male pereiopod 2; (19) male pereiopod 3; (20) male pereiopod $4 ;(21)$ male pereiopod $7 ;(22)$ female pereiopod $1 ;(23)$ female pereiopod 2; (24) female pereiopod 3; (25) female pereiopod 4; (26) female pereiopod 7; (27) male pereiopod 1 carpus; B. olfersii: (28) male pereiopod 7 merus; arrow indicates unique lobe with 6 setae. Scales: (17-26) $500 \mu \mathrm{m}$; (27) $100 \mu \mathrm{m}$; (28) $200 \mu \mathrm{m}$. 
Benthana cairensis sp. nov. is commonly abundant in leaf litter and under fallen tree branches of Araucaria angustifolia (Bert.) O. Ktze., the only native conifer in Brazil. While classified as runners following Schmalfuss (1984), this species is also capable of thanatosis.

\section{ACKNOWLEDGEMENTS}

The authors wish to thank FAPERGS/PROAPP 0409925 for financial support. This is contribution number 516 of the Departamento de Zoologia, Universidade Federal do Rio Grande do Sul.

\section{LITERATURE CITED}

Araujo, P.B. \& A. LeistiKow. 1999. Philosciids with pleopodal lungs from Brazil, with description of a new species (Crustacea, Isopoda). Contributions to Zoology 68 (2): 109-141.

Araujo, P.B. \& E.R.C. Lopes. 2003. Three new species of Benthana Budde-Lund (Isopoda, 'Philosciidae') from Brazil. Journal of Natural History 37 (20): 2425-2439.

Leistikow, A. 2001. Phylogeny and biogeography of South American Crinocheta, traditionally placed in the family "Philosciidae" (Crustacea: Isopoda: Oniscidea). Organisms Diversity and Evolution 1 (Electronic Supplement): 1-85.
Leistikow, A. \&. P.B. Araujo. 2001. Morphology of respiratory organs in South American Oniscidea (Philosciidae), p. 329336. In: B. Kensley \& R. Brusca (Eds). Isopods Systematics and Evolution. Rotterdam, A.A. Balkema, vol. 13, 357p.

Leistikow, A. \& P.B. Araujo. 2006. The systematic position of Benthanoscia longicaudata Lemos de Castro, 1958 (Isopoda: Oniscidea: Crinocheta). Systematics and Biodiversity 4 (3): 243-254.

Leistikow, A. \& J.W. Wägele. 1999. Checklist of the terrestrial isopods of the new world (Crustacea, Isopoda, Oniscidea). Revista Brasileira de Zoologia 16 (1): 1-72.

Lemos de CASTRO, A. 1958a. Benthanoscia longicaudata, a new genus and species of terrestrial isopod of the family Oniscidae (Isopoda, Oniscoidea). American Museum Novitates 1884: 1-7.

Lemos de Castro, A. 1958b. Revisão do gênero Benthana BuddeLund, 1908 (Isopoda, Oniscidae). Arquivos do Museu Nacional 46: 85-118.

Schmalfuss, H. 1984. Eco-morphological strategies in terrestrial isopods, p. 49-63. In: S.L. SutTon \& D.M. Holdich (Eds). The Biology of Terrestrial Isopods. Symposium of the Zoological Society of London 53. Oxford, Clarendon Press, 518p.

VANDEL, A. 1962. Isopodes Terrestres (Deuxieme partie). In: Faune de France. P. Lechevalier, Paris, 66: 417-931.

Submitted: 05.VII.2007; Accepted: 23.V.2008.

Editorial responsibility: Georgina Bond-Buckup 